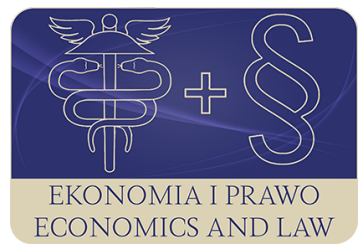

EKONOMIA I PRAWO. ECONOMICS AND LAW

Volume 16, Issue 2, June 2017

p-ISSN 1898-2255, e-ISSN 2392-1625

www.economicsandlaw.pl

ORIGINAL ARTICLE

received 14.06.2017; revised 25.06.2017; accepted 30.06.2017

Citation: Klimach, A., \& Źróbek, R. (2017). Substituted property in expropriation of real estate: the case of Poland. Ekonomia i Prawo. Ecomomics and Law, 16(2): 141-157. doi:10.12775/EiP.2017.010.

\title{
Substituted property in expropriation of real estate: the case of Poland
}

\author{
ANNA KLIMACH
}

corresponding author

University of Warmia and Mazury in Olsztyn, Faculty of Geodesy, Geospatial and Civil Engineering, Department of Real Estate Resources, ul. Prawocheńskiego 15, 10-720 Olsztyn, Poland $\square$ anna.klimach@uwm.edu.pl

\section{RYSZARD ŹRÓBEK}

University of Warmia and Mazury in Olsztyn, Faculty of Geodesy, Geospatial and Civil Engineering,

Department of Real Estate Resources

$\square$ rzrobek@uwm.edu.pl

\begin{abstract}
Motivation: Substituted property is a concept appearing, among other places, in the real property expropriation procedure. Its most frequent use is in the context of granting an equivalent of expropriated property. Historically, this concept has been used in reference to different regulation.

Aim: In this article the statutory definition of substituted land (parcel) has been found and its ongoing pertinence subjected to analysis.

Results: A new definition of substituted property is proposed along with amendment of the provisions of the Real Property Management Act (1997), one which may contribute to popularizing the concept of substituted property as an equivalent of expropriated real estate.
\end{abstract}

Keywords: substituted property; expropriation; procedure; compensation; similar property JEL: K11; K19; K25; H13; H82; P14 


\section{Introduction}

This article aims to define substituted property. This is a concept used also in the real property expropriation procedure. This article explains how the concept of substituted land is understood in Polish law.

The real property expropriation procedure is relatively complex and comprises numerous detailed topics. The majority of them may be the scope of separate study, beginning from what may be the object of expropriation and ending with the restoration of expropriated property. The importance of analysis of the expropriation procedure is significant because it pertains to either deprivation or restriction of the right of ownership, perpetual usufruct or other limited real rights in real property. Familiarity with each and every element of the expropriation procedure is important not only for the entity putting the expropriation procedure to application but also for the user of the property on which the procedure is going to be used.

\section{Literature review}

This article contains research based on many laws and regulations. The most important one is Real Property Management Act (RPMA, 1997). This Act includes basic information about expropriation. RPMA was created in 1997 and many articles was changed but articles about expropriation was not changed very much. Regulations concerning expropriation don't change very often this institution has some invariable elements. There are some acts about expropriation which change some elements e.g. time, among of money. Right now urban construction code is under preparation. This code will contain articles about expropriation of real estate. This regulations have the same content as in RPMA (1997). Legislator use the concept of substituted property however this concept is not explain. In this connection authors account that this concept should be treated the same way as in the RPMA (1997).

References to the substituted property can also be found in the literature of a subject. Information about substituted property has been mention in many articles, monograph and comments on the laws. None of this source presents definition of this concept that can be satisfactory for authors.

\section{Methods}

In the article authors use a typical for law sciences formal-dogmatic method. An analysis of legal acts, case law and literature was conducted to find explanation of the concept of substituted property Substituted property is used in expropriation of real property. The RPMA (1997) doesn't explain what this term means.

The authors sought to identify what substituted property mean, how to understand this concept. 


\section{Expropriation of real property}

Expropriation is a procedure to acquire land for public purposes and appears in multiple countries. Similarities with regard to this procedure are abundant, yet significant differences also apply. Attention is concentrated on the rules for determining compensation and especially the possibility of receiving substituted property in exchange for the property being expropriated.

International law does not prevent states from expropriating real property, but the following conditions must be met, usually jointly:

- the property is necessary to accomplish public purposes,

- the expropriation procedure must be consistent with the law,

- no manifestations of discrimination are allowed.

- compensation must be awarded for the property expropriated (OECD, 2004, p. 3).

Article 1 of Protocol 1 of the European Convention of Human Rights (1952) provides for the protection of property of every natural and legal person. Such a person may be deprived of property: 'in the public interest and on term and subject to the conditions provided for by law and by the general principles of international law'. The Convention allows for the right of ownership to be restricted by legislation. Expropriation may take place in the public interest. As noted in the study entitled Roads and the Environment (Tsunokawa \& Hoban, 1997, p. 122), those affected by expropriation are not only the owners of real property. In many countries there are multiple different forms of control of real property (often informal or unregistered). Expropriation, therefore, affects not only proprietors or those in control but also third parties. Those may be persons taking advantage of services provided on the property or visiting those in possession of it. Expropriation pertains mostly to deprivation of a right to the property, but it may have a broader sphere of effect, e.g. deprivation of revenue from a business located on the property.

Expropriation as a procedure is a balancing act between public needs and private property. Authorities authorized to expropriate real property usually receive their powers from the provisions of their country's constitution (FAO, 2008, p. 12). The procedure typically comes in several stages, such as: planning, publicizing, appraisal and filing requests, payment of compensation, possession, abandonment of the intended expropriation, restitution (FAO, 2008, p. 16).

The goal of planning and publicizing the expropriation procedure is to inform the society of what works are to be carried out and to consider the opinions of stakeholders. Such opinions should be elaborated and delivered (FAO, 2008, p. 19). Notice should be given as soon as possible. This will allow the time to object against the takeover of property, apply for compensation or appeal against ill-executed procedures (FAO, 2008, p. 20). The aim of publicizing the knowledge is also to show the stakeholders what the expropriation procedure entails (FAO, 2008, p. 21). 
Appraisal of the property is conducted variously, depending on the provisions of the law in force in the relevant country. The appraisal may be prepared by agencies or by specially authorized persons. Negotiations to acquire the property already before the expropriation proceedings may also occur.

Expropriated property may be compensated with money or resettlement (FAO, 2008, p. 38) (substituted property). Resettlement does not always lead to a grant of identical property. Differences may result from physical characteristics such as lack of water access, less fertile soil. They may also arise from the resettling of such persons to other areas, of which the inhabitants may be less than welcoming to unfamiliar newcomers. Resettlers may also encounter different economic conditions (e.g. labour market, compensation level) than they did in the original location (FAO, 2008, p. 40). Individual countries give different shapes to their rules for determining compensation for expropriated property and the possibility of receiving substituted property in exchange for the expropriated property.

Time-frames for the payment of compensation differ according to the provisions of the law of the relevant country. Compensation also entails the option to appeal against the estimated amount. Owners usually believe that the estimate is insufficient, and they lodge appeals accordingly.

Expropriation procedure in Poland is regulated by the RPMA (1997) and other specific legislation. Provisions regarding expropriation for highway construction are located in the Act of 27 October 1994 on Toll Highways and the National Road Fund (1994). The Act of 28 March 2003 on Rail Transport (Rail Transport Act, 2003) contains provisions regulating real property expropriation for railway construction.

Analysis of Article 21 of the Constitution of the Republic of Poland (1997) shows that only general protection of the right to own property is contained in that Article. The provision does not state precisely whether expropriation applies to all things movable and immovable or to real property alone. The Constitution (1997), refers to the concept of property, which can be understood either in the meaning given to it by the private law or in its broad meaning. In its private-law meaning, property means the right of ownership, other economic rights and the right of inheritance. In the broader meaning, property means one's possessions (Woś, 1995, p. 29). In the Constitutional Court resolution of 11 January 1995 the Court determined that property in the understanding of Article 7 of the Constitution of the People's Republic of Poland of 1952 was a synonym of possessions (Judgement of Constitutional Court of 11 January 1995, W 11/94). Three decisions of the Constitutional Court may be cited for reference with regard to the Constitution currently in force. In its decision of 12 January 1999 the Court ruled that: 'Article 21 does not provide for the protection of economic rights other than ownership in its civil-law meaning' (Judgement of Constitutional Court of 12 January 1999, P 2/98). 'The constitutional understanding of property exceeds the civil-law definition', is the conclusion from the Judgement of Constitutional Court of 21 March 2000 (K 14/99). The ruling 
under discussion is no longer up to date. In 2003 the Court took a position from which it shows that Article 21 protects trademark rights (Judgement of Constitutional Court of 28 January 2003, K 2/02). Analysis of these Constitutional Court rulings prompts notice that the notion of 'property' is undergoing modification to give it a broader construction. Changes in jurisprudence are bringing the right to own property closer and closer to the concept of possessions.

Since the right to own property protected by Article 21 of the Constitution (1997) is close in meaning to one's possessions, there is still a question whether movable property can be expropriated. Article 112 of the RPMA (1997) provides for the expropriation of property. Therefore, the issue of expropriating a movable thing does not seem to be of significance. The RPMA (1997) narrows expropriation down to real property alone and it also shows which property can undergo expropriation. For contrast, perhaps it is worth citing M. Szalewska's (2005, pp. 124-125) view that Article 21 of the Constitution (1997) allows movable things and non-material goods to be the objects of expropriation.

Article 21 of the Constitution (1997), contains the rule that expropriation may take place only with fair compensation. The other prerequisites are:

- only real property may be expropriated;

- property targeted for expropriation must be intended for public purposes in local development plans (areas intended for the pursuit of a public goal, or a decision has been issued to determine the location of a public-purpose project);

- the beneficiary of expropriation may be either the Treasury or a unit of territorial self-government;

- expropriation may take place only for a public purpose;

- the property being expropriated is necessary for the achievement of that public purpose;

- the property cannot be acquired in any other way than through expropriation;

- expropriation takes place with fair compensation.

Compensation is assessed by the expropriating authority (RPMA, 1997, Articles 128-135). This compensation may be determined in the expropriation decision itself or in a separate decision. The amount of compensation is assessed on the basis of an expert appraiser's opinion determining the value of the property (market value or replacement value). It is also possible to receive substituted property as a form of compensation for expropriated property.

Article 6 of the RPMA (1997) contains a catalogue of public purposes for which property can be expropriated. This catalogue in relation to RPMA (1997) is a closed catalogue. Public purposes may be listed in other laws (Bończak-Kucharczyk, 2013, p. 89). 


\section{Substituted property as a form of compensation for expropriation of real property}

The expression 'substituted property' appears only in Division III, Chapters 4-6 RPMA (1997). There is no definition of such property in the Act. On the other hand, one can find expressions such as 'property being exchanged', 'properties being exchanged'. Those expressions are used with reference to real property exchange between the Treasury and units of territorial self-government, between such units themselves, and between the Treasury or units of territorial self government and natural or legal persons. Exchange of real properties is provided for in Articles 14-15 of Act on Real Property Management and Articles 603-604 of the Civil Code (1964). These provisions mandate that property may be exchanged if the parties are consenting. It seems the lawmaker ought not to use different expressions to refer to one and the same legal institution. It must be concluded that with regard to property received in compensation for expropriation of real property the concept of substituted property is used. Provisions of the Civil Code concerning exchange do not use the expression 'substituted property'. In this connection, it should be concluded that substituted property is granted as an exchange in the understanding of the Civil Code.

The Act charges the expropriating authority with the obligation to negotiate in order to enable conveyance through a civil-law contract. During such negotiations a substituted property may be proposed to the user of the property being expropriated. One cannot speak here of substituted property in the same sense as that awarded in compensation for expropriated property, given that it is not granted by means of a decision issued by the authority, since the right to the property is conveyed on the basis of the intention of the parties. Additionally, it does not seem proper to speak about substituted property in this place because no expropriation proceedings have been initiated yet. The lawmaker introduces a certain inconsistency here by using this expression even though expropriation proceedings have not started yet. The exchange takes place under real property exchange provisions, i.e. Article 15 RPMA (1997) and provisions of the Civil Code. It is still unclear what exchanged property is to be provided as an equivalent awarded for the expropriation - is that any property for which the expropriated entity agrees to exchange the expropriated property or are there some rules regulating (indicating) what property it is supposed to be. Exchanged property, therefore, is not substituted property. Substituted property occurs when there are already pending proceedings and the amount or method of compensation for the expropriated property can be determined. Exchanged property is thus not substituted property. This, however, does not answer the question of what property that should be. In the provisions concerning exchange the lawmaker does not state in precise language whether the property being exchanged should have any characteristics in common (e.g. location). This introduces the possibility of compensating the difference between the value of the property being exchanged. Article 603 of the Civil Code (1964) contains 
the statement that an exchange is to be understood as a state in which a subject of an obligation relationship undertakes to convey the right of ownership of a thing in exchange for an undertaking to convey the right of ownership of some other thing. It does not follow from here what property the one being exchanged is to be. The conclusion should probably be that a proposed exchange may involve the offer of any real property which is available to the Treasury or to units of self-government. It will then be the expropriated entity's decision whether to accept such property or not.

\section{Select definitions of substituted property}

There is no definition of substituted property in the RPMA (1997). This expression appears solely in reference to the property one may receive as the equivalent of expropriated property.

The Act of 29 May 1957 on the Settlement of Ownership Matters of Certain Non-Agricultural Properties in Reclaimed Territories and in the territory of the former Free City of Gdańsk (Free City of Gdańsk Act, 1957) also contained expressions concerning substituted property. Such property was granted where it was not possible to award the ownership of properties owned by subjects and taken over by the State as post-German or derelict property and confiscated by former German authorities in connection with the owners' political activities. Article 5 of the Act defined cases in which the ownership of real property could not be awarded. Then, in accordance with Article 6, substituted property was awarded. With the subject's consent it was possible to grant property of a different type from the property substituted for.

Regulation of the Council of Ministers on the rules and procedure for granting substituted properties and financial compensation for certain non-agricultural properties in Reclaimed Territories and in the territory of the former Free City of Gdańsk (Free City of Gdańsk Regulation, 1958) (hereinafter referred to as the 'Regulation') defined the understanding of substituted property. In accordance with $\$ 2$ of the Regulation, substituted property should have corresponded to the property substituted for as to its character, outfitting, location and size. Thus, the concept of substituted property was introduced in the Regulation - 'it is real property which the subject may receive in exchange for properties left behind in Reclaimed Lands and in the territory of the former Free City of Gdańsk'. The conveyance took place by means of a resolution constituting the basis on which to enter into an exchange contract. The contract was made in the form of a notarial deed.

An attempt to compare similar expressions to substituted property is made below (similar property). The definition of similar property is provided in Article 4.16 RPMA (1997). Similar property is property comparable to the appraised property on account of its location, legal status, purpose, method of use and other characteristics affecting its value. The goal of this comparison is to determine whether similar and substituted property are the same property or 
are they two different concepts. Similar property appears the most frequently in the focus of interest of the academia and jurisprudence, making it easier to define similar property or even provide an example of it. Attention can be called here to elements both definitions have in common.

Table 1 shows comparative of two features 'substituted property' and 'similar property'.

It can be noted that 'similar property' and 'substituted property' have some features in common. Character and purpose are not synonyms, but their meaning is close enough to regard them as equivalents. The closest concept to the property's character is probably its purpose. Additionally, the character of the property could include its method of use and legal status. The notion of the character of property is wide enough to accommodate multiple different concepts.

Still, one cannot put an equal sign between substituted property and similar property. The two concepts are different and apply to different procedures in real property management.

The second sentence of $\$ 2$ of the 1958 Regulation mandates that: With the consent of the person entitled to be granted substituted property, the substituted property granted may be of a different kind or size. It is therefore possible to receive property not exactly corresponding to the characteristics of the substituted property. From this it follows that with the party's consent it is possible to receive property which is not the same as the expropriated property. The possibility was also introduced to pay the difference between the value of the substituted property and the expropriated property.

The problem occurs also in acts concerning the relationship between the Polish State and various Churches and religious associations. It is on the basis of those acts that regulations have been enacted referring to grants of substituted property.

In the Regulation of the Council of Ministers of 14 June 1999 on determining state organizational units and territorial self-government units from the assets of which substituted properties may be separated and determining the state organizational unit which may be charged with the obligation to pay compensation to the legal persons of the Polish Autocephalous Orthodox Church (Autocephalous Orthodox Church Act, 1999) one can find reference to concept of substituted property (the subject may obtain substituted property in exchange for real property). The expression 'substituted property' does not appear, though, but only the resource out of which it may be granted. This regulation is not the only one of its type. A similar one has been enacted for Jewish religious communities or the Union of Jewish Religious Communities in Poland (Union of Jewish Religious Communities in Poland Act, 1999), legal persons of the Evangelical Church of the Augsburg Confession in the Republic of Poland (Evangelical Church of the Augsburg Confession in the Republic of Poland Act, 2001), the legal persons of churches, other religious associations and national interchurch organizations having lodged claims before the Interchurch Regulation 
Commission (Interchurch Regulation Commission Act, 1999). The lawmaker uses the concept of substituted property without either redefining it or providing that it should be understood the way it was defined in the 1958 Regulation. It should probably be accepted that if a definition had been mandated in 1958, then it was not necessary to copy the definition of 'substituted property' in other provisions.

Another legislative act making use of the concept of substituted property is the Spatial Planning and Development Act (2003). In a situation when a local plan has been approved or changed, it may become impossible use the property in accordance with its current purpose, or the possibility may be restricted. In such a case, the owner or perpetual usufructuary may claim compensation for the actual damage incurred or force purchase of the property or part of it. The duty to compensate occurs when the subject has incurred actual damage. This follows from the October 2007 judgment of the Supreme Court (Judgement of Supreme Court of 12 October 2007, V CSK 230/07). The damage must be a consequence of the plan change. Only where the damage has actually happened is it possible to raise claims against the municipality. A different opinion can be found in Judgement of Supreme Court of 19 December 2006 (V CSK 332/06), in which the Supreme Court asserts that the claim may be brought by the owner or usufructuary where the change or adoption of a plan prevents the continued use of the property in the same method or prevents the use of the property in accordance with its current purpose. It is similar where the change or establishment of a plan imposes significant restrictions on the use of the property. The municipality may then propose substituted property to the owner or perpetual usufructuary. The act does not determine whether the owner may apply for exchange of the property for substituted property. The 2012 Act contains a mention that the municipality may offer substituted property. The Act mandates that such property shall be conveyed under a contract of exchange. It is not defined what happens when the value of the expropriated property and the substituted property differ. The value of the property may increase or decrease in connection with the establishment or change of the local plan. Following the guidelines in the Regulation of the Council of Ministers on the rules and procedure for granting substituted properties and financial compensation for certain non-agricultural properties in Reclaimed Territories and in the territory of the former Free City of Gdańsk, substituted property should be similar to the property at hand regarding its: character, outfitting, location and size. It is not possible to find identical property to be substituted property. Therefore, additional payments should be made between the parties.

There is again an inconsistency concerning substituted property. Perhaps not as much the property itself as the method of the conveyance of it. In the 1958 Regulation of the Council of Ministers substituted property is conveyed by a resolution, in the RPMA (1997) by an administrative decision, and in the Spatial Planning and Development Act (2003) by a contract. A ruling from the Voivodeship Administrative Court in Gliwice asserts that matters provided for in Article 
36.1-3 of the Spatial Planning and Development Act (2003), therefore connected with an exchange of real property, may not be resolved by an administrative decision. There is no legal basis on which to issue a decision regarding real property exchange (Judgement of Voivodeship Administrative Court in Gliwice of 16 November 2006, II SA/Gl 318/06). A resolution or decision are acts of governance issued by an authority. A contract is a unanimous expression of the intention of its parties. Even where the substituted property is granted by means of an administrative decision, such as when expropriation takes place, that does not mean the property being granted is not first accepted by the subject.

\section{Substituted apartment/office}

The RPMA (1997) also provides for the grant of a substituted apartment or office in exchange for the one being expropriated. Expropriation of an apartment or office is possible thanks to the provision enabling expropriation of real property and real rights in it. The provision also mentions rentees of expropriated apartments or offices. From this it follows that one does not need to be the owners of an apartment or office in order to receive substituted property. It is necessary to determine what a substituted apartment or office is and whether the concept of substituted apartment or office has the same meaning as substituted real property or are those separate concepts. RPMA (1997) provides no definition of a substituted apartment or office. A definition can be found in the Act on the Protection of Tenants, Municipal Apartment Resource, and Amendment of the Civil Code (2001). In reliance on the interpretive principle of the rational lawmaker, that definition should be regarded as binding for the entire branch of the law. An additional argument in favour of regarding the definition of the substituted apartment or office as one intended for the entire branch of the law and not only for the one act can be found in the fact that the Housing Co-operative Act (2000) refers to the definition contained in this act.

According to the Act, a substituted apartment or office is one located in the same inhabited community as the one in which the current apartment or office is located; outfitted with at least the same technical facilities as the current apartment or office, with the same size of rooms; this condition is deemed fulfilled where there is a total of $10 \mathrm{~m}^{2}$ of total room space per member of the household, and $20 \mathrm{~m}^{2}$ for one-member households. The definition does not account for the purpose of the substituted apartment or office. It does not follow from it whether the substituted apartment or office must serve the same purpose as the current one or is it enough that it fulfils the remaining criteria such as outfitting or size.

As can be inferred from table 2, the concepts of substituted property, similar property and substituted apartment or office are not coextensive. The concepts of substituted property and substituted apartment or office are the closest to being equivalent to each other. The only difference between them is the 'character' feature of the property. However, it seems that the substituted apartment 
or office should have a similar character and purpose. The definition of similar property seems to be the broadest one thanks to the addition that in searching for similarity other features may be considered. Therefore, there is no obstacle to the inclusion of the outfitting or size of the property as such other features. The concept of 'similar property' was coined mostly for appraising needs and should be used in reference to determining the value of the right.

While determining compensation for expropriated property, it is sufficient to rely on the concept of substituted property. In the authors' opinion, it cannot be said that, in searching for substituted property, property similar to the property being expropriated is being sought. Even should that property fulfil the prerequisites of substituted property and similar property, it will be substituted property. Only when compared in an appraisal process will it be regarded as similar property. Thus, there is no need to consider whether substituted property is similar property. They may fulfil the same prerequisites, and it may be one and the same property, but it is the procedure which determines which property one is dealing with. Another problem remains, though, because in searching for property to be granted to the subject as an equivalent of the expropriated property, it is necessary to consider what property that should be. In an exchange of property it is the subject who makes the decision to exchange property. Therefore, the subjective principle is followed with regard to the measure of the benefit in transactions. If the parties decide that the relevant thing is equivalent to their own thing, it may be regarded as such (Bieniek, 2011, p. 143). If the exchange is taking place under Article 14 RPMA (1997), the exchange may take place without compensating for the difference in value, and therefore with no obligation to pay the difference together with the right worth less. Article 14 of the aforementioned act describes the exchange of property between the Treasury and units of territorial self-government, as well as between different units of territorial self-government. Article 15 , on the other hand, refers to exchange between the Treasure or territorial self-government units and natural or legal persons. That Article does not permit omission of a payment compensating for the difference in the value of the right exchanged. In a situation in which there are significant differences in the value of property being exchanged, no economic detriment for either party may be permitted. Neither does compensation being paid for the expropriated property leave room for omission of the equal value of the property.

The value of substituted property must be the same as the value of the expropriated property. There remains an option to make good the difference in value by making additional payments. Question arises as to what should happen when the subject who is to receive substituted property is interested in property of a different character, for example desiring to receive an apartment in return for the subject's land with an inhabitable house on it. If the apartment or office fulfils the prerequisites to be a separate apartment and is part of the resource available to the appropriate unit of territorial self-government or the Treasury, can such an apartment be made a separate apartment? In this connection, can 
such an apartment be designated as substituted property? Such a possibility would solve the problems of expropriated house owners because it would be possible for them to receive an apartment to which they could relocate. However, the RPMA (1997) does not contain a provision enabling the subject to be granted substituted property of a different character from expropriated property. The lack of such a provision prevents from the point of view of the law the grant of substituted property of a different character.

\section{Conclusion}

It ought to be considered whether the definition of substituted property from 1958 remains up to date and whether a definition should not perhaps be added to the RPMA (1997). In keeping with the provisions of the 1958 Regulation, substituted property should correspond to the property substituted for as to its character, outfitting, location and size. Under linguistic canons of interpretation, the character should be regarded as a collection of features characteristic of the relevant thing or phenomenon, distinguishing it from other things and phenomena of the same kind (Stownik Języka Polskiego, 2017). In the definition of similar property attention is given to its purpose. The purpose (Polish: przeznaczenie) is: a practical goal for which something is intended or qualified or which the thing serves (Stownik Języka Polskiego, 2017). Purpose is the more correct notion with regard to real property. The goal and not the character is then emphasized. What matters is how to distinguish it from other things. The subjective understanding of those words alone is different. Character (Polish: character) is associated more with a human person than with a thing when it does not indicate what the thing could be used for. Then, the outfitting prerequisite follows. Legislative acts use the expression: 'equipped with technical infrastructure facilities'. RPMA (1997), in its Article 143.2, shows what needs to be understood by construction of technical infrastructure facilities - road construction and the construction of underground, ground or overhead water supply, sewage, heating, power, gas and telecommunication cables or devices. Adding: 'property equipped with technical infrastructure facilities' does not lead to unclear language. All the more so because outfitting real property with technical infrastructure facilities affects its value, while other outfitting may be judged subjectively.

The wording of a new definition of similar property should be: 'The substituted property should correspond to the expropriated property as to its purpose, outfitting with technical infrastructure facilities, location and size'. The definition should also allow for the subject wishing to receive substituted property to receive, with that subject's consent, property serving a different purpose. Transplantation of the provision from the 1958 Regulation would produce legal basis for the grant of different property with a different purpose from the property being expropriated. That could lead to substituted land being employed more frequently as an equivalent of expropriated property. Real property resources 
of a territorial self-government unit contain property with different purposes, which means it would be easy to find property acceptable to the subject. Provision should be made for the fact that users of property intended for their residential needs are forced to acquire some other property in order to continue to provide for those needs.

Substituted property is not only property referred to in the RPMA (1997). The concept finds application also in other procedures involving real property. It is always property which can be received in return for our own property lost according to the provisions of the law. There are multiple ways of conveying substituted property such as an administrative decision, resolution or contract between the parties. The greatest difficulty, however, lies in determining what the substituted property should be, whether it should be the most similar property to the property being expropriated or it can be any property which is accepted. Under the RPMA (1997) it is not permissible to receive e.g. a residential apartment in return for developed land.

\section{References}

Bieniek, G. (Ed.). (2011). Ustawa o gospodarce nieruchomościami. Komentarz. Warszawa: LexisNexis.

Bończak-Kucharczyk, E. (2013). Ustawa o gospodarce nieruchomościami. Komentarz. Warszawa: Wolters Kluwer.

FAO. (2008). Compulsory acquisition of land and compensation. Retrieved 12.06.2017 from http://www.fao.org.

Judgement of Constitutional Court of 11 January 1995. W 11/94, Lex no 25585.

Judgement of Constitutional Court of 12 January 1999. P 2/98 (OTK 1999/1/2), Lex no 36155.

Judgement of Constitutional Court of 21 March 2000. K 14/99 (OTK 2000/2/61), Lex no 39994.

Judgement of Constitutional Court of 28 January 2003. K 2/02 (OTK-A 2003/1/4), Lex no 74917.

Judgement of Supreme Court of 12 October 2007. V CSK 230/07, Lex no 485903.

Judgement of Supreme Court of 19 December 2006. V CSK 332/06, Lex no 421051.

Judgement of Voivodeship Administrative Court in Gliwice of 16 November 2006. II SA/G1 318/06, Lex no 930193.

Konstytucja Rzeczypospolitej Polskiej z dnia 2 kwietnia 1997 r. [Constitution of the Republic of Poland of 2 April 1997] (Dz.U. 1997 nr 78 poz. 483) (Poland).

OECD. (2004). 'Indirect expropriation' and the 'right to regulate' in international investment law. OECD Working Papers on International Investment, 4. doi:10.1787/780155872321. 
Protokół nr 1 do Konwencji o ochronie praw człowieka i podstawowych wolności, sporządzony w Paryżu dnia 20 marca 1952 r. oraz Protokół nr 4 do powyższej konwencji, sporządzony w Strasburgu dnia 16 września 1963 r. [Protocols No. 1 (Paris, 20 March 1952) and No. 4 (Strasbourg, 16 September 1963) to the Convention for the Protection of Human Rights and Fundamental Freedoms] (Dz.U. 1995 nr 36 poz. 175) (Poland).

Rozporządzenie Rady Ministrów z dnia 14 czerwca 1999 r. w sprawie określenia państwowych jednostek organizacyjnych oraz jednostek samorządu terytorialnego, z których mienia mogą być wyłączone nieruchomości zamienne, oraz określenia państwowej jednostki organizacyjnej, na którą może być nałożony obowiązek zapłaty odszkodowania na rzecz osób prawnych kościołów, innych związków wyznaniowych i krajowych organizacji międzykościelnych, które zgłosiły roszczenia do Międzykościelnej Komisji Regulacyjnej [Regulation of the Council of Ministers of 14 June 1999 on determining state organizational units and territorial self-government units from the assets of which substituted properties may be separated and determining the state organizational unit which may be charged with the obligation to pay compensation to the legal persons of churches, other religious associations and national interchurch organizations having lodged claims before the Interchurch Regulation Commission] (Dz.U. 1999 nr 53 poz. 552) (Poland).

Rozporządzenie Rady Ministrów z dnia 14 czerwca 1999 r. w sprawie określenia państwowych jednostek organizacyjnych oraz jednostek samorządu terytorialnego, z których mienia mogą być wyłączone nieruchomości zamienne, oraz określenia państwowej jednostki organizacyjnej, na którą może być nałożony obowiązek zapłaty odszkodowania na rzecz gmin wyznaniowych żydowskich lub Związku Gmin Wyznaniowych Żydowskich [Regulation of the Council of Ministers of 14 June 1999 on determining state organizational units and territorial self-government units from the assets of which substituted properties may be separated and determining the state organizational unit which may be charged with the obligation to pay compensation to Jewish religious communities or the Union of Jewish Religious Communities in Poland] (Dz.U. 1999 nr 53 poz. 553) (Poland).

Rozporządzenie Rady Ministrów z dnia 14 czerwca 1999 r. w sprawie określenia państwowych jednostek organizacyjnych oraz jednostek samorządu terytorialnego, z których mienia mogą być wyłączone nieruchomości zamienne, oraz określenia państwowej jednostki organizacyjnej, na którą może być nałożony obowiązek zapłaty odszkodowania na rzecz osób prawnych Polskiego Autokefalicznego Kościoła Prawosławnego [Regulation of the Council of Ministers of 14 June 1999 on determining state organizational units and territorial self-government units from the assets of which substituted properties may be separated and determining the state organizational unit which may be charged with the obligation to pay compensation to the legal persons of the Polish Autocephalous Orthodox Church] (Dz.U. 1999 nr 53 poz. 554) (Poland). 
Rozporządzenie Rady Ministrów z dnia 31 marca 1958 r. w sprawie zasad i trybu przyznawania nieruchomości zamiennych oraz wynagrodzenia pieniężnego za niektóre nieruchomości nierolnicze na Ziemiach Odzyskanych i na terenach b. W. M. Gdańska [Regulation of the Council of Ministers of 31 March 1958 on the rules and procedure for granting substituted property and financial compensation for certain non-agricultural properties in Reclaimed Territories and in the territory of the former Free City of Gdańsk] (Dz.U. $1958 \mathrm{nr} 20$ poz. 86) (Poland).

Rozporządzenie Rady Ministrów z dnia 9 października 2001 r. w sprawie państwowych jednostek organizacyjnych oraz jednostek samorządu terytorialnego, z których mienia mogą być wyłączone nieruchomości zamienne, oraz określenia państwowej jednostki organizacyjnej, na którą może być nałożony obowiązek zapłaty odszkodowania na rzecz osób prawnych Kościoła Ewangelicko-Augsburskiego w Rzeczypospolitej Polskiej [Regulation of the Council of Ministers of 9 October 2001 on determining state organizational units and territorial self-government units from the assets of which substituted properties may be separated and determining the state organizational unit which may be charged with the obligation to pay compensation to the legal persons of the Polish Evangelical Church of the Augsburg Confession] (Dz.U. 2001 nr 128 poz. 1410) (Poland).

Słownik Języka Polskiego. (2017). Retrieved 12.06.2017 from http://sjp.pwn. pl.

Szalewska, M. (2005). Wywtaszczenie nieruchomości. Toruń: Dom Organizatora. Tsunokawa, K., \& Hoban, C. (Ed.). (1997). Roads and the environment: a handbook. World Bank Technical Paper, 376.

Ustawa z dnia 15 grudnia 2000 o spółdzielniach mieszkaniowych [Housing Co-operatives Act of 15 December 2000] (Dz.U. 2013 poz. 1222) (Poland).

Ustawa z dnia 21 czerwca 2001 r. o ochronie praw lokatorów, mieszkaniowym zasobie gminy i o zmianie Kodeksu cywilnego [Protection of Tenants, Municipal Apartment Resource, and Amendment of the Civil Code Act of 21 June 2001]. (Dz.U. 2016 poz. 1610) (Poland).

Ustawa z dnia 21 sierpnia 1997 r. o gospodarce nieruchomościami [Real Property Management Act of 21 August 1997] (Dz.U. 2016 poz. 2147) (Poland).

Ustawa z dnia 23 kwietnia 1964 r. - Kodeks cywilny [Civil Code of April 23, 1964] (Dz.U. 2017 poz. 459) (Poland).

Ustawa z dnia 27 marca 2003 r. o planowaniu i zagospodarowaniu przestrzennym [Spatial Planning and Development Act of 27 March 2003] (Dz.U. 2017 poz. 1073) (Poland).

Ustawa z dnia 27 października 1994 r. o autostradach płatnych oraz o Krajowym Funduszu Drogowym [Toll Highways and the National Road Fund Act of 27 October 1994] (Dz.U. 2017 poz. 1057) (Poland).

Ustawa z dnia 28 marca 2003 r. o transporcie kolejowym [Rail Transport Act of 28 March 2003] (Dz.U. 2016 poz. 1727) (Poland). 
Ustawa z dnia 29 maja 1957 o uregulowaniu spraw własności niektórych nieruchomości nierolniczych na Ziemiach Odzyskanych i na terenach b. W. M. Gdańska [Settlement of Ownership Matters of Certain Non-Agricultural Properties in Reclaimed Territories and in the territory of the former Free City of Gdańsk Act of 29 May 1957] (Dz.U. 1957 nr 31 poz. 137) (Poland).

Woś, T. (1995). Wywtaszczenie nieruchomości i ich zwrot. Poznań, Kluczbork: Wydawnictwo Stowarzyszenia Notariuszy Rzeczypospolitej Polskiej.

\section{Acknowledgements}

Author contributions: authors have given an approval to the final version of the article. Authors contributed to this work equally.

Funding: this research was fully funded by the Department of Real Estate Resources, Faculty of Geodesy, Geospatial and Civil Engineering, University of Warmia and Mazury in Olsztyn statutory funds (28.610.02.300). 


\section{Appendix}

Table 1.

Comparative features of 'substituted property' and 'similar property'

\begin{tabular}{cc}
\hline $\begin{array}{c}\text { Substituted property } \\
(\$ 2 \text { of the Regulation })\end{array}$ & $\begin{array}{c}\text { Similar property } \\
\text { (RPMA, 1997, Article 4.16) }\end{array}$ \\
\hline character & purpose \\
outfitting & - \\
location & location \\
size & - \\
- & legal status \\
- & method of use \\
- & other features \\
\hline
\end{tabular}

Source: Own preparation.

\section{Table 2.}

Comparison of the concepts of substituted property, similar property and substituted apartment or office

\begin{tabular}{|c|c|c|}
\hline $\begin{array}{l}\text { Substituted property } \\
\text { ( } \$ 2 \text { of the Regulation) }\end{array}$ & $\begin{array}{c}\text { Similar property } \\
\text { (RPMA, 1997, Article 4.16) }\end{array}$ & $\begin{array}{c}\text { Substituted apartment or office } \\
\text { (Protection of Tenants, Municipal } \\
\text { Apartment Resource, and change } \\
\text { of the Civil Code Act, 2001, Article } \\
\text { 2.1.6) }\end{array}$ \\
\hline character & purpose & - \\
\hline outfitting & - & $\begin{array}{l}\text { outfitted at least with such technical } \\
\text { facilities as those in the apartment } \\
\text { or office currently used. }\end{array}$ \\
\hline location & location & $\begin{array}{l}\text { located in the same inhabited } \\
\text { community. }\end{array}$ \\
\hline size & - & $\begin{array}{l}\text { room surface the same as in the cur- } \\
\text { rently used apartment or office } \\
\text { (other sizes as defined in the act are } \\
\text { permissible) }\end{array}$ \\
\hline - & legal status & - \\
\hline - & method of use & - \\
\hline- & other features & - \\
\hline
\end{tabular}

Source: Own preparation. 
